\title{
Unabated Corruption in the Government of Nigeria Despite the Economic and Financial Crimes Commission: Who Bells the Cat?
}

\author{
Salisu Ojonemi PAUL* \& Prof. Chikelue Ofuebe, PhD \\ Public Administration and Local Government Studies, \\ University of Nigeria, Nsukka \\ *Corresponding Author: Salisunelson@gmail.com \\ https://riiopenjournals.com/index.php/society sustainability/index
}

Doi: https://doi.org/10.38157/society sustainability.v2i2.129

Citation: PAUL, S. O. \& Ofuebe, C. (2020). Unabated Corruption in the Government of Nigeria Despite the Economic and Financial Crimes Commission: Who Bells the Cat? Society \& Sustainability, 2(2), 45-58. Doi: https://doi.org/10.38157/society_sustainability.v2i2.129

\section{Research Article}

\begin{abstract}
This paper examines the different dimensions and continuous corrupt practices in the federal government of Nigeria amidst President Buhari administration's anti-corruption songs and war (2015 - date). It is observed that the menaces of infrastructural deficits are persistent and unabated due to billions of dollars that are carted away by both political and public office holders on a seasonal basis, and misfit appointment of public officials popularly referred to as 'favoritism' and the 'lopsidedness.' The study which is qualitative with data gathered from secondary sources. The paper found the fact that political and public office holders across administrations in Nigeria perceived corruption as a worthwhile venture despite the campaign against corruption. It is also noticed that the EFCC created to lead anti-corruption war only barks without biting. The study advocated, among others, that the National Assembly should immediately reevaluate and review the Nigeria administration of criminal justice system.
\end{abstract}

Keywords: Corruption, the EFCC, the Government, Public Office Holders, Political System, Nigeria

\section{Introduction}

Nigeria is richly endowed with oil and gas resources, but the country's continued reliance on loans from international financial institutions raises questions about the transparency and accountability of its utilization of the huge revenues resulting from these two resources... [which] continues to be used corruptly... (Bakre \& Lauwo, 2016:45).

Corruption, though one of the concepts in social sciences which have occupied local, international, management, and development discourse, the phenomenon has reached a hydra- 
headed degree bothering the liveliness of the Nigerian state (Joshua \& Oni, 2014). Since independence, the delivery of critical infrastructural development projects and the workings of government institutions have been negatively affected by corrupt practices among the managers of resources in Nigeria. According to France (2019), this development has inevitably made the creation and strengthening of agencies that will ensure the necessity of anti-corruption campaign. The war against corruption is not a local institutional affair. There are international institutions like Transparency International (TI), United Nations (UN), Organisation of Economic Cooperation and Development (OECD), European Bank for Reconstruction and Development (EBRD), World Bank (WB), World Trade Organisation (WTO), and the International Monetary Fund (IMF). The engagement of these institutions in anti-corruption war is a pointer to the fact that strong institutions are the main determinants of social and economic development above public policies in the contemporary period. Significantly, the performance of any nation's economy is based on the convergence and growth of institutional framework.

Nigeria is made up various organs and institutions that are responsible for the survival and stabilisation of the economy for accelerated national development. The importance of institutionalisation of the activities and programmes of Nigerian government under the President Obasasnjo's civilian regime (1999 - 2007) being premised on the challenges of underdevelopment facing the country demonstrated a strong political will by the creation of the Economic and Financial Crimes Commission (EFCC) in 2004. This is because of the inability of most anti-corruption approaches to achieve concerted efforts in curbing corrupt practices affecting all sectors of the Nigerian economy over many decades (Orokpo, 2018). In addition, the federal government of Nigeria is challenged with a standing history of poor service rendering in critical sectors, of which are not far-fetched from the power supply, education, medical services, portable water, post and telecommunications, environmental services, transport, and aviation, and oil and gas.

According to Nwaodu, Adam \& Okereke (2014), the creation of EFCC became imperative in order to handle the arrests, interrogation, investigation, and prosecution of alleged corrupt individuals who have served and are still serving in both the public and private sector. However, the agency has not been living up to expectation in the performance of the aforementioned responsibilities, thereby putting its reliability and stewardship to the public in doubt.

Efforts to strengthen institutions have not been prioritized by policy makers in Nigeria because of their corrupt practices. More so, President Buhari that won 2015 and 2019 presidential elections on "Anti-corruption Campaign and Posture" is not free of the 'corruption, virus.' The administration as it can be observed defied her responsibility and commitment which Johari (1989:251) cited by Orokpo \& Stephen (Nd) are essentially characterized by the fact;

i. "Government is a difficult art and any wrong move entails serious consequences. Therefore, it is the duty of every conscientious person to interest him seriously in the management of public affairs. It is required that those placed in high offices should direct their thought and action to the general good. Political obligations are not only of an intellectual character; they also involve obligation of an honest and what is called public office. 
ii. The concept of political obligation automatically involves the case of political legitimacy and effectiveness. While political effectiveness implies actual performance in the light of the extent to which the political system provides for the performance of basic functions of government as the people and powerful groups in society, then the case of political legitimacy refer to the capacity of the system to engender and maintain the belief that the existing social, economic and political institutions are more appropriate for society.

iii. The idea of political obligation not only informs people to obey the authority of those in power, it also desires them to be critical about the way authority is exercised. They should scrutinize the actions of their rulers and resent in the event of any invasion on their liberties. Thus, the idea of political obligation involves the case of resistance to authority."

From the foregoing background, this article shall discuss the implications of the study, dimension, extent, and forms of corruption in Nigeria, the creation of EFCC and its attendants' challenges in the anti-corruption campaign, and vital recommendations.

The nature of the paper is principally qualitative, and the sources and method of data gathering are secondary. Relevant information as obtained through consultation from the EFCC Act 2004 and other government publications, peer reviewed journal articles, newspapers, textbooks, and internet resources.

\section{Corruption in Nigeria: Dimensions, Extent, and Forms}

The five richest men in Nigeria could bring nearly all Nigerians out of extreme poverty for one year... between 1960 and 2005, \$20 trillion was stolen by public office holders and multinational companies received tax incentives of $\$ 2.9$ billion a year. The richest Nigerian man will take 42 years to spend all his wealth AT 11 million per day. In one day, the richest Nigerian man can earn from his wealth 8,000 times more than what the poorest $10 \%$ of Nigerians spend on average in one year for their basic consumption

(Oxford Committee for famine Relief cited by Ojo, 2020:16).

No sector of the Nigerian economy is free from the 'viruses' of corrupt practices. Though very prevalent in all climes, countries are ranked in this facet. Corruption is described as an anti-social behavior conferring improper benefits contrary to legal and moral norms, and which undermines the governmental capacity to protect and make provision for the welfare of all citizens (Osoba, 1996). It is a demonstration of dishonest and illegal behavior by public office holders (Ogbuke \& Enojo, 2007, in Ibietan, 2015). According to Nigerian Vice President Osinbajo (2016), no sector and organ of government in Nigeria are exempted from corruption. Corruption dynamics vary in Nigeria. It deals with interaction and agreement among interested individuals which Keeper (2010:173) noted is intended towards "changing the structure or process of society.... in order to produce dishonest, unfaithful, or undefiled situations." It is seen as an active and multifaceted social phenomenon due to its descriptive dynamics, proliferation, impacts, and perceived manifestations that have three parties that include "the principal, agent, and the client" (Klitgaard, 1988 in Ayoola, 2013:683). Thus, Ogbodo (2015) asserted that corruption happens 
before the open stealing that is rather visible and attracts loud condemnation. Okeyim, Ejue \& Ekanem (2013); Page (2018) posited that its typology occurs in the form of bureaucratic/public sector corruption, political/electoral corruption and vote-buying, bribery in cash and kind, embezzlement and misappropriation, extortion and exploitation, favoritism and nepotism, and fraud.

In Nigeria, corruption is observed as a tool of exploitation by the owners of resources and taxpayers by the heads of government, their middlemen (civil servants, traditional and religious leaders), and other members of the political class. This attitude has assumed the primary way of private accumulation of wealth at the detriment of development and service delivery which are the seals of leadership. As Achebe (2012:249) contended, “... the problem of corruption and indiscipline is probably worse today than it's ever been, because of the massive way in which the Nigerian leadership is using the nation's wealth to corrupt, really to destroy, the country, so no improvement or change can happen." For instance, the World Bank stated that Nigeria needs about $\$ 14$. 2billion per year to bridge the huge infrastructure gap and with about $\$ 10$. 5billion needed for federal infrastructure alone (Ojo (2016) (See appendix I and II). In the same development, there is a deficit in capacity utilization where the right people are not being appointed into the right position to do the right thing at the right time for the development of the country. According to Imhonopi \& Urim (2016); Harris (2017); Achcar et al (2017); and Andrade (2019), corruption have transformed lower-level employees of both public and private sector organisations into cheap laborers in their own country and has enriched few individuals against the downtrodden masses. It is the 'dictator and director' of Nigeria's religious, political, social, and economic life. Osoba (1996:371) stressed that;

\begin{abstract}
All subsequent regimes, military and civilian, have been pervaded by corruption aided and enhanced by oil revenues, [which] has created a deepening crisis of kleptocracy, shown in most extreme form since 1984. It results in a combination of scandalous wealth among the ruling class with growing poverty, misery, and degradation among the mass of Nigerians. Political life has become dominated by winner-take-all factional struggles, political cynicism, and violence, while the economy and social institutions have been driven into decay (Osoba, 1996:371).
\end{abstract}

Corruption remains the distinct dreaded challenge that has debarred Nigeria from realizing her great prospects. The enormous amounts of monies running into billions of dollars and trillions of Nigeria Naira have been drained. It has knocked out several development agendas and weakens the social contract between the government and the people since colonialism and postindependence Nigeria (Page, 2018). For example, Ojo (2016:22) conceived that "a whooping $¥ 41.6$ trillion was made as revenue from crude oil proceeds and taxes, as well as duties between fiscal years of 2011 - 2014 and most of it, flowed into private purses". In effect, the Ministries and ExtraMinisterial Departments and Agencies (MDAs), State and Local governments are not finding easy to pay salaries and wages of their employees who do not constitute $10 \%$ population. 
Table 1: Corruption Profile in Nigeria

\begin{tabular}{|c|c|c|c|c|c|}
\hline $\mathbf{S} / \mathbf{N}$ & Names & $\begin{array}{l}\text { Position Held in } \\
\text { Government }\end{array}$ & Administrative Panel & $\begin{array}{c}\text { Alleged Stolen } \\
\text { Amount }\end{array}$ & Date \\
\hline 1. & Dr. Nnamdi Azikiwe & $\begin{array}{c}\text { Eastern Regional } \\
\text { Premier/President of } \\
\text { Nigeria }\end{array}$ & The Foster-Sutton Tribunal & $£ 163,000$ & 1952 \\
\hline 2. & $\begin{array}{l}\text { Chief Obafemi } \\
\text { Awolowo, }\end{array}$ & $\begin{array}{l}\text { Western Regional } \\
\text { Premier/Minister }\end{array}$ & Coker Commission of Inquiry. & f6.2 million & 1962 \\
\hline 3. & Alh. Shehu Shagari & $\begin{array}{c}\text { Minister/President of } \\
\text { Nigeria }\end{array}$ & $\begin{array}{c}\text { Buhari/Idiagbon Military } \\
\text { Regime }\end{array}$ & $\$ 16$ billion & $1979-1983$ \\
\hline 4. & Alh. Umar Dikko & Minister & $\begin{array}{c}\text { Buhari/Idiagbon Military } \\
\text { Regime }\end{array}$ & N 4 billion & 1982 \\
\hline 5. & $\begin{array}{l}\text { Gen. Ibrahim } \\
\text { Babangida }\end{array}$ & $\begin{array}{c}\text { Head of } \\
\text { State/Military } \\
\text { President } \\
\end{array}$ & Okigbo Panel Report & $\$ 12.4$ billion & $1988-1994$ \\
\hline & Gen. Sani Abacha & Head of State & $\begin{array}{l}\text { The Economic and Financial } \\
\text { Crimes Commission (EFCC) }\end{array}$ & $\begin{array}{l}\text { Ongoing } \\
\text { discovery and } \\
\text { recovery of the } \\
\text { loot }\end{array}$ & $1993-1998$ \\
\hline 6. & $\begin{array}{c}\text { President Olusegun } \\
\text { Obasanjo, }\end{array}$ & $\begin{array}{c}\text { Head of State/Civilian } \\
\text { President }\end{array}$ & $\begin{array}{c}\text { Vincent Azie, Auditor- } \\
\text { General of the Federation } \\
\text { Report }\end{array}$ & $\begin{array}{l}\$ 400 \text { million } \\
\$ 23 \text { billion }\end{array}$ & 2002 \\
\hline & $\begin{array}{c}\text { President Olusegun } \\
\text { Obasanjo, }\end{array}$ & $\begin{array}{c}\text { Head of State/ } \\
\text { Civilian President }\end{array}$ & $\begin{array}{l}\text { Hon. Ndidi Elumelu House of } \\
\text { Reps Power Project Report }\end{array}$ & $\$ 16$ billion & $1999-2007$ \\
\hline 7. & $\begin{array}{l}\text { Jackson Gaius- } \\
\text { Obaseki }\end{array}$ & $\begin{array}{c}\text { Group Managing } \\
\text { Director, Nigeria } \\
\text { National Petroleum } \\
\text { Corporation (NNPC) }\end{array}$ & $\begin{array}{c}\text { Haman Tukur, Chairman of } \\
\text { led Revenue Moblisation, } \\
\text { Allocation and Fiscal } \\
\text { Commission (RMAFC). }\end{array}$ & $\$ 302$ billion & 2002 \\
\hline 8. & $\begin{array}{l}\text { Chief Anthony } \\
\text { Anenih }\end{array}$ & Federal Minister & $\begin{array}{l}\text { The Federal Ministry of } \\
\text { Works }\end{array}$ & $\$ 300$ billion & $1999-2003$ \\
\hline 9. & $\begin{array}{l}\text { Hussaini Akwanga } \\
\text { Chief S. M. Afolabi } \\
\text { Mahmud Shata, } \\
\text { R. O. Akerele, } \\
\text { Okwesilieze Nwodo, } \\
\text { Niyi Adelagun, }\end{array}$ & $\begin{array}{l}\text { Federal Minister } \\
\text { Federal Ministers }\end{array}$ & $\begin{array}{c}\text { Report of the investigation } \\
\text { into the award of National } \\
\text { Identity Card project to } \\
\text { SAGEM S.A., }\end{array}$ & $\$ 214$ million & $2001-2003$ \\
\hline 10. & $\begin{array}{c}\text { President Goodluck } \\
\text { Jonathan }\end{array}$ & President of Nigeria & $\begin{array}{l}\text { The Mallam Nuhu Ribadu } \\
\text { Report }\end{array}$ & \$31 million & $2010-2012$ \\
\hline 11. & Abdulrasheed Maina & $\begin{array}{l}\text { Chairman of the } \\
\text { Presidential Pension } \\
\text { Reform Task Team }\end{array}$ & $\begin{array}{l}\text { The Economic and Financial } \\
\text { Crimes Commission (EFCC) }\end{array}$ & 195 billion & 2012 \\
\hline 12. & Mr. Andrew Yakubu & $\begin{array}{l}\text { Group Managing } \\
\text { Director, NNPC }\end{array}$ & $\begin{array}{l}\text { The Economic and Financial } \\
\text { Crimes Commission (EFCC) }\end{array}$ & $\begin{array}{c}\$ 9,772,800 \\
\text { million }\end{array}$ & 2017 \\
\hline 13. & $\begin{array}{c}\text { Mrs. Diezani } \\
\text { Alison-Madueke }\end{array}$ & Federal Minister & $\begin{array}{l}\text { The Economic and Financial } \\
\text { Crimes Commission (EFCC) }\end{array}$ & $\begin{array}{l}\text { and } \$ 487.5 \\
\text { andion } \\
\text { million in cash } \\
\text { and properties }\end{array}$ & $2011-2015$ \\
\hline 14. & Col. Sambo Dasuki & $\begin{array}{c}\text { National Security } \\
\text { Adviser }\end{array}$ & $\begin{array}{l}\text { The Economic and Financial } \\
\text { Crimes Commission (EFCC) }\end{array}$ & $\$ 2.1$ billion & $2011-2015$ \\
\hline 15. & $\begin{array}{c}\text { Mr. David Babachir } \\
\text { Lawal }\end{array}$ & $\begin{array}{l}\text { Secretary to the } \\
\text { Government of the } \\
\text { Federation }\end{array}$ & $\begin{array}{l}\text { Sen. Shehu Sani Senate Adhoc } \\
\text { Committee on IDP Camp }\end{array}$ & $\begin{array}{l}\text { 200 million } \\
\text { (bush clearing) }\end{array}$ & 2016 \\
\hline 16. & Ibrahim Idris & $\begin{array}{l}\text { Inspector General of } \\
\text { Police } \\
\end{array}$ & $\begin{array}{c}\text { Sen. Isah Misau Senate } \\
\text { Committee on Police Affairs }\end{array}$ & N10 billion & 2017 \\
\hline 17. & Maikanti Baru & $\begin{array}{l}\text { Group Managing } \\
\text { Director, NNPC }\end{array}$ & $\begin{array}{c}\text { Hon. The Kachikwu, Federal } \\
\text { Minister of State for } \\
\text { Petroleum Resources }\end{array}$ & \$25 billion & 2017 \\
\hline
\end{tabular}

Source: The authors' compilation.

Table 1 pictures the extent of financial crimes in Nigeria from pre-independence to the postindependence era and it is noticeable that allegation of stolen public funds from 1999 to date was higher than the 1990s. From table 1 also, it is discovered that the special interest of Nigerian leaders is excessive capital accumulation. "Incontrovertibly, corruption became endemic in the 1990s during the military regimes of Babangida and Abacha, but a culture of impunity spread throughout the political class when democracy returned to Nigeria in 1999" (Ogbeidi, 2012). Some of these funds that have been alleged to be diverted were meant to rehabilitate, restructure and reshape dilapidated infrastructures (see appendix IV). The table is without the 36 States executive and legislative members because of the scope of the study - the Federal Government of Nigeria. In another development, actors in the Nigerian political stage use integrity, accountability, and open-door policy as slogan which does not in any way manifest in legitimate and realistic ethical behavior in government. "This gap between rhetoric and practice is not at least evident if we consider the many high-profile corruption scandals that have taken place in Africa during the last couple of years" (Persson, Rothstein \& Teorell, 2010:19). Therefore, the former vice president of Nigeria (1999 - 2007), Atiku Abubakar, who was also the opposition party's (PDP) candidate in 
the 2019 presidential election listed alleged corrupt officials of Buhari's government and among others to include the following.

Table 2: List of Alleged Corrupt Buhari Associates from 2015 - Date

\begin{tabular}{|c|c|c|c|}
\hline $\mathbf{S} / \mathbf{N}$ & Names & Position in APC and Buhari's Government & Amount Alleged to have Stolen \\
\hline 1. & Abdullahi Adamu & Former Governor and Serving Senator (APC) & \$15 billion \\
\hline 2. & Folarin Coker & $\begin{array}{l}\text { Director General, Lagos socialite and Nigerian } \\
\text { Tourism Development Corporation (NTDC) }\end{array}$ & \#3 billion \\
\hline 3. & Bola Tinubu's & $\begin{array}{c}\text { Owner of Alpa Beta Consultancy and National } \\
\text { Leader of the All Progressive Congress } \\
\end{array}$ & $¥ 100$ billion Alpha Beta \\
\hline 4. & Abba Kyari & Presidential Chief of Staff, 2015 - 2020 & $\begin{array}{c}\text { \$500million MTN } \\
\$ 29.9 \text { million contract scam }\end{array}$ \\
\hline 5. & Babachir Lawal & $\begin{array}{c}\text { Former Secretary to the Government of the } \\
\text { Federation (SGF) }\end{array}$ & $\begin{array}{l}\text { N450 million in kickbacks from } \\
\text { companies that got contracts from PINE }\end{array}$ \\
\hline 6. & $\begin{array}{l}\text { Lt. Gen. Tukur } \\
\text { Buratai }\end{array}$ & Chief of Army Staff & \$1.5million Dubai mansions \\
\hline 7. & Senator Hadi Sirika & Minister of Aviation & $¥ 1.2$ billion Nigeria Air fraud scandal \\
\hline 8. & $\begin{array}{l}\text { Hajia Aisha Buhari's } \\
\mathrm{N} 2.5 \mathrm{~b}\end{array}$ & Wife of the President & N2.5billion \\
\hline 9. & Adedayo Thomas, & $\begin{array}{l}\text { Executive Director, National Film and Video } \\
\text { Censors Board }\end{array}$ & $\begin{array}{l}\$ 50 \text { million and stealing of the } \\
\text { organization's } 500 \text { KVA generator }\end{array}$ \\
\hline 10. & Adamu Muazu & $\begin{array}{l}\text { Former governor of Bauchi State, and a APC } \\
\text { leading member. }\end{array}$ & \#19.8 billion \\
\hline 11. & Sen. Iyiola Omisore & $\begin{array}{c}\text { A former deputy governor of Osun State, Senator } \\
\text { and a leading member of the APC. }\end{array}$ & $\$ 1.3$ billion \\
\hline 12. & $\begin{array}{l}\text { Sen. Musiliu } \\
\text { Obanikoro }\end{array}$ & $\begin{array}{c}\text { A Senator and former Minister of State for Defense, } \\
\text { and a leading member of the APC }\end{array}$ & $\$ 4.7$ billion \\
\hline 13. & Orji Uzor Kalu & $\begin{array}{c}\text { A former governor of Abia State and APC Senate } \\
\text { Chief Whip }\end{array}$ & N3.2 billion \\
\hline 14. & Issa Yuguda & $\begin{array}{l}\text { A former governor of Bauchi State, Minister of } \\
\text { Aviation and leading member of the APC }\end{array}$ & $\# 200$ billion \\
\hline 15. & $\begin{array}{l}\text { Sen. Godswill } \\
\text { Akpabio }\end{array}$ & $\begin{array}{c}\text { A former governor of Akwa Ibom State, Senate } \\
\text { Minority leader the Buhari's Minister of Niger } \\
\text { Delta Affairs }\end{array}$ & $¥ 108$ billion \\
\hline 16. & $\begin{array}{l}\text { Vice President Yemi } \\
\text { Osinbajo }\end{array}$ & The Buhari's Vice President & $\begin{array}{l}\$ 5.8 \text { billion NEMA fraud and the } \\
\text { flagrant violation of procurement laws }\end{array}$ \\
\hline 17. & Abdullahi Ganduje & The APC serving governor of Kano State & $\begin{array}{l}\text { Disclosed video of the American Dollar } \\
\text { collection }\end{array}$ \\
\hline 18. & Saminu Turaki & $\begin{array}{c}\text { Former Jigawa State governor and a leading } \\
\text { member of the APC. }\end{array}$ & \#5.2 billion \\
\hline 19. & Junaid Abdullahi & $\begin{array}{c}\text { The Executive Secretary at the Border Agency, and } \\
\text { an in-law to President Mohammadu Buhari }\end{array}$ & $\begin{array}{l}\$ 1.3 \text { billion Border Agency } \\
\text { multimillionaire contract }\end{array}$ \\
\hline & Sen. Aliyu Wamako & $\begin{array}{l}\text { A former deputy governor, two term governor and } \\
\text { a serving APC Senator from Sokoto State }\end{array}$ & \# 15 billion \\
\hline 20. & $\begin{array}{l}\text { Sen. Hope } \\
\text { Uzodimma }\end{array}$ & $\begin{array}{l}\text { A former Senator and an APC serving governor of } \\
\text { Imo State }\end{array}$ & $\begin{array}{l}\text { \$12million contract for the dredging of } \\
\text { the Calabar port channel }\end{array}$ \\
\hline 22. & $\begin{array}{l}\text { Rt. Hon. Rotimi } \\
\text { Amaechi }\end{array}$ & $\begin{array}{l}\text { A former 8years Speaker of the Rivers State House } \\
\text { of Assembly, two term governor, two term } \\
\text { minister of Transport and the Director-General of } \\
\text { the Buhari Campaign Organisation in 2015, and } \\
2019\end{array}$ & $\begin{array}{l}\$ 97 \text { billion through the sale of Rivers } \\
\text { State valued assets }\end{array}$ \\
\hline 23. & Abdul'aziz Yari & Former two term APC governor of Zamfara State & $\begin{array}{l}\text { N680million said from the Paris Club } \\
\text { refunds. }\end{array}$ \\
\hline
\end{tabular}

Source: Atiku (2019), and reviewed by the authors 
Also, table 2 above shows President Muhammadu Buhari's appointees and party members with various corruption allegations despite his anti-corruption campaigns in the 2015 and 2019 presidential elections. During the 2019 electioneering campaign, he maintained,

In the fight against corruption, I assure you that all those who have fraudulently enriched themselves when they were entrusted with public funds, we will eventually get them and deal with them. We are doing it; we will continue to do it and I assure you; we will not abuse your trust.

Nevertheless, the administration is not free of high-level corruption accusations. In addition, corruption took a different dimension under the administration of President Muhammadu Buhari as it has faced fierce criticism over the lopsided appointment, particularly in the defense and security architecture and 'Grade A' agencies in the Nigerian public sector. It is observed that the entirety of Nigerian security architecture (Armed Forces, the Police, and Paramilitary) is handled by Northerners. Earlier, Eme \& Onuigbo (2016) and Eme \& Okeke (2017) said citizens of the nation have perceived discrimination, arbitrariness, bias, and danger in the Buhari's presidential appointments made from 2015 - date. Accordingly, Nnanna (2020) argued that most top government jobs and appointments are made up of Northerners of Muslim faith extraction, while some drop-offs are being given to southerners. These appointments are the;

- SGF - Boss Mustapha (Adamawa),

- Independent National Electoral Commission (INEC) - Prof. Mahmood Yakubu (Bauchi),

- Federal Character Commission (FCC) - Mohammed Tukur Secretary (Adamawa)

- Nigerian National Petroleum Corporation (NNPC) - Mele Kolo Kyari (Borno),

- Department of Petroleum Resources (DPR) - Sarki Auwalu,

- Petroleum Product Pricing and Regulatory Agency (PPPRA)-Abdulkadir Saidu Umar (Katsina),

- Petroleum Trust and Development Fund (PTDF) - Bello Gusau (Nasarawa),

- Nigeria Ports Authority (NPA) - Hajia Hadiza Bala Usman (Kaduna),

- Nigerian Maritime Administration and Safety Agency (NIMASA) - Dr. Bashir Yusuf Jamoh (Kaduna),

- National Communication Commission (NCC) - Umaru Dambatta (Kano),

- National Directorate of Employment (NDE) - Nasiru Ladan (Niger),

- Nigerian Defense Academy (NDA) - Major General Sarham Jamilu (Kano),

- Nigeria Police Academy (POLAC) Wudil, Assistant Inspector General of Police (AIG) Zanna Mohammed (Borno),

- Nigeria Drug Law Enforcement Agency (NDLEA) - Muhammad Abdallah (Adamawa),

- Economic and Financial Crimes Commission - DCP, Mohammed Umar

- Federal Inland Revenue Service (FIRS) - Muhammad Nami (Niger),

- Nigeria Customs Service (NCS) - Col. Hammed Ali (rtd.),

- Nigerian Immigration Service (NIS) - Kure Martin Abeshi (Nassarawa),

- National Population Commission (NPC) - Ghaji Bello (Gombe),

- Asset Management Corporation of Nigeria (AMCON) - Edward Lamekek Adamu (Gombe),

- Federal Mortgage Bank of Nigeria (FMBN) - Ahmed Dangiwa (Kaduna), 
- Bank of Industry (BoI), Dikko AbdulRahman (Borno),

- Rural Electrification Agency (REA) - Umaru Maza Maza (Kebbi),

- Federal Airports Authority of Nigeria (FAAN) - Hamisu Rabiu Yadudu (Kano),

- Nigeria Railway Corporation (NRC) - Usman Abubakar (Katsina),

- Nigerian Meteorological Agency (NiMet) - Prof. Sani Abubakar Mashi.

- Nigerian College of Aviation Technology (NCAT), Zaria - Capt. Abdulsalam Mohammed (Kogi),

- Nigeria Deposit Insurance Corporation (NDIC) - Umaru Ibrahim (Kano),

- Nigeria Civil Aviation Authority (NCAA) - Capt. Musa Nuhu,

- Department of State Security (DSS) - Yusuf Magaji Bichi (Kano),

- Nigerian Security and Civil Defense Corps (NSCDC) - Abdullahi Muhammadu (Niger),

- National Primary Health Care Development Agency (NPHCDA) - Dr. Faisal Shaibu,

- Federal Capital Development Authority (FCDA) - Umar Gambo Jibrin (Bauchi),

- Securities and Exchange Commission (SEC) - Lamido Yuguda,

- Nigeria Incentive-based Risk Sharing System for Agricultural Lending (NIRSAL) - Aliyu Abbati Abdulhameed (Adamawa),

- National Universities Commission (NUC) - Professor Abubakar Adamu Rasheed (Kaduna),

- National Commission for Colleges of Education (NCCE) - Professor Bappa-Aliyu Muhammadu (Bauchi), and among others.

The heads of these organizations are all from the northern region of Nigeria where the president hails from. That in itself is termed corruption by many followers of political events in Nigeria because the act is not only money stolen. For example, these itemized appointments portray 'corruption' resulting from the fact that further than producing incompetent and rotten leadership and government, it challenges the provisions of the 1999 Constitution of the Federal Republic of Nigeria as amended which emphasizes the Federal Character Principle. The drafters of the 1999 constitution borrowed the Federal Character Principle section 14 [3] from resolutions of the Constitutional Conference convened by the late General Sani Abacha, 1994 - 1996 which targeted at ending sectionalism in the federal government of Nigeria (Nnanna, 2020).

As a result of this development, some factors have been discovered to be responsible for all corrupt practices in Nigeria across successive administrations in Nigeria. It is observed that the superstructure of the economy and political style of Nigeria cannot set aside as major causes of corruption. To this end, Orokpo Ogbole (2018:20) asserted that "often, when the subject is discussed in developing countries especially, poverty, unemployment, greed, weak institutional and moral values, inadequate checks and balances, poor remuneration for civil servants, weak and corrupt criminal justice system, among others, are identified as the immediate causes of financial crime."

\section{The Challenges of EFCC in Anti-Corruption Campaign: A Debate}

The pervasiveness of fraudulent practices in Nigeria necessitated the enactment of laws and the creation of EFCC. Despite the existence of the EFCC, cases of economic and financial crimes dominated the media. This depicts the inability of the commission, to 
some extent, to tackle fraudulent practices in Nigeria [due to] mostly internal and external factors (Umar, Shamsiah \& Bin Mohamed, 2016).

Poverty, unemployment, and underdevelopment in Nigeria, despite the presence of abundance, human, natural, and material resources has been traced to corrupt practices among stakeholders in a Nigerian development project. Corruption negatively impacts both direct and indirect development and investment together with investment in the economy (Swaleheen, 2011).

The extent of socioeconomic and political development cannot be divorced from constituted institutional structures within the nation (Dutt, 2009; Umoh \& Ubom, 2012; Nwaodu, Adam \& Okereke, 2014). Following the high rate of integrity challenge among the managers of public and private businesses and resources, successive administrations in Nigeria initiated several institutions to put an end to the ugly trend. As Umoh \& Ubom (2012) submitted, they include but not limited to "the Corrupt Practices Decree of 1975; the War against Indiscipline and Corruption (WAIC) campaign; the Code of Conduct Bureau of 1990; the Advance Fee Fraud and other Related Offences Decree of 1995, and the Independent Corrupt Practices Commission." The most recent among these is the EFCC (Nwaodu, Adam \& Okereke, 2014).

The anti-graft agency derives its existence from "Section 15 sub-section 5 of the 1999 Constitution of the Federal Republic of Nigeria as amended" where, "the state shall abolish all corrupt practices and abuse of power." Substantially in 2004, the Bill for an Act to legally support the waging of war against corruption was assented by the then President Olusegun Aremu Obasanjo. Concisely, the cardinal responsibilities of the Commission as stated in the Act $(2004: 2,3)$ include but not limited to;

i. "the investigation of all financial crimes including advance fee fraud, money laundering, counterfeiting, illegal charge transfers, contract scam, etc.;

ii. the adoption of measures to identify, trace, freeze, confiscate or seize proceeds derived from terrorist activities, economic and financial crimes related offenses or the properties the value of which corresponds to such proceeds;

iii. the facilitation of rapid exchange of scientific and technical information and the conduct of joint operations geared towards the eradication of economic and financial crimes; and iv. Collaborates with government bodies both within and outside Nigeria carrying on functions wholly or in part analogous with those of the Commission."

Moreover, though the 2004 Act emphasizes independence of the commission in all ramifications, the situation is opposite. Jaguar (2017) argued that this formed part of the continuous challenges of the inability of the government to carry out its duties and responsibilities to her citizens stems from the absence of trust, legitimacy, reliability, and satisfaction. There is disputable concern with the process of the Commission's Chairmanship appointment, communication channel, and the termination procedure. The development under these scenarios poses an unanswered, serious ingenuity, integrity, and independence questions. According to Inokoba \& Ibegu (2011); Oke (2014); and Olutokun (2020), serial arbitrary termination of the appointment of the Commission's Chair by successive administration signifies excessive political intrusion and influence. The issue is more compounded due to the role of the executive that deals with the provision of policy framework, financing and administration of all the agency's activities. 
Presently, DCP Ibrahim Magu who was alleged to have fallen out with the nation's AttorneyGeneral and Minister of Justice, Abubakar Malami (SAN) has been replaced with DCP Umar Mohammed on acting capacity from the same the Northern region and ethnic background of Nigerian President, Muahmmadu Buhari. Fundamentally, it was only Farida Waziri (Mrs.) that possesses north-central origin out of all the successive chairmen of the Commission who emerged from the North. As Oke (2020) argued, this signals the relegation of ethnic-heterogeneity factor to non-issue in a multi-ethnic nation as Nigeria. In addition, the restriction placed on the appointment of the Commission's Chair by the 2004 Act, 2 (1) (ii) poses another challenge. It stated that the Chairman shall be only a "serving or retired member of any government security or law enforcement agency not below the rank of Assistant Commissioner of Police (ACP) or equivalent."

The EFCC has been alleged to be meddling with political affairs. The former ruling Party (APC) chairman Adams Aliu Oshiomole (2019) said, "we have quite a number of other PDP leaders who have come... in fact, once you have joined APC, all your sins are forgiven." This confirms the transformation of the Commission into the apparatus of witch-hunt of opposition parties' members in Nigerian democratic setting. Moreover, there is duplicity and overlapping of functions between the EFCC, DSS, ICPC, and the Nigerian Police. The resultant effect of this is inter-agency squabbles and unhealthy rivalry which has thwarted the coordination of the war against corruption particularly in the Buhari's administration. Similarly, the "lacuna" and unfavorable nature of the administration of the criminal justice system, paucity of fund, and under-utilization of capacity in the EFCC are also challenges. Therefore, it can be summed that the agency is not performing due to the politicization of the war against corrupt practices, lack of political-will, ethnicization of the EFCC headship, clash of roles and functions among sisteragencies, and inordinate administration of criminal justice system.

\section{Conclusion and Recommendations}

(With heavy reliance on secondary data, this paper has argued the fact that political and public office holders' across administration in Nigeria from pre-independence to date perceived corruption as a worthwhile venture despite the anti-corruption war. The discourse also demonstrated that the performance of EFCC in the anti-corruption campaign has credibility and integrity questions to answer before Nigerians. It is also established that the high level of the dearth of infrastructures - housing, roads (as shown in appendixes I and II) and poverty of power supply, and systems' failure widely experienced in Nigeria are results of corruption. Considering the foregoing, we recommend the following for further necessary actions.

i. Though there are corruption allegations against the National Assembly, the organ should immediately reevaluate and review the Nigerian administration of the criminal justice system to squarely deal with individuals who have made corruption as a worthwhile venture. This will clear her from image in the public domain.

ii. The EFCC should be strengthened and rescued from executive-hijackers through the amendment of the 'EFCC Act, 2004' to make it credible and independent of the executive in theory and practice. 
iii. The Auditor General of the Federation power should be intensified by law to audit and address deficits in the awards of contracts for the development of critical infrastructures.

iv. The civil society, labor and trade union organizations, and the citizens should emphasize town-hall meetings in order to address the unanswered questions in leadership accountability and systems' failure in Nigeria.

\section{Implications of the Study}

It is not an understatement to apparently state that corruption has been the major responsible factor for the stunted growth of Nigeria in terms of socio-economic, political, and critical infrastructural development even after 60 years of her existence as a nation. Educational and health institutions built by the missionaries during colonialism are now in dilapidated conditions in various parts of the country (see appendix III). Though there are allegations and counterallegations between the Executive, Legislative, and Judicial arms of government, the realization of substantial outcomes in decreasing the consequences of corruption depends on their actions and inactions.

This study is therefore a concerted effort to call on relevant organs of the Nigerian State most importantly the National Assembly, the Judiciary, the civil society/labor and trade union organizations, and citizens to assist in rescuing the "Economic and Financial Crimes Commission" and the enforcement of leadership accountability that is lacking in the body polity. It further identifies the current dynamics in corrupt practices apart from popular bureaucratic/public sector corruption, political/electoral corruption and vote-buying, bribery in cash and kind, embezzlement and misappropriation, fraud, extortion and exploitation to bias and discrimination in the appointment of public office holders - a menace that characterizes the President Muhammadu Buhari's administration (2015-2023). Furthermore, it is an addition to the literature for further debate on the challenges to accountability, good governance, infrastructural development-deficit and system failure in both under-developed, and developing of the world.

Authors' Contribution: Salisu Ojonemi PAUL wrote the article under the tutelage and direct supervision of Prof. Chikelue Ofuebe, PhD.

Conflict of interest: The authors declare no conflict of interest.

\section{REFERENCES}

Achcar, G., Abdelkarim, N., Abboud, S., Said, S., Kamal, A., Abdelhaliem, R. \& Stiftung, F. E. (2017). Towards Socially Just Development in the MENA Region, Friedrich-Ebert-Stiftung, Germany

Achebe, C. (2012). There was a country: A personal history of Biafra. London: Penguin Books Ltd.

Andrade, D. (2019). Populism from above and below: Agriculture and the Political Ambiguities of the Workers' Party in Brazil. In Conference paper: Authoritarian Populism and the Rural World.

Anyebe, A. A. (2017). Entrepreneurship education and employment in Nigeria. International Journal of Academic Research in Business and Social Sciences, 7(3), 739-747.

Atiku, A. (2019). Nigeria: Atiku releases list of 'corrupt' Buhari associates. Premium Times. Accessed from https://allafrica.com/stories/2019 on 19/6/2020 
Ayoola, T. (2013). The effect of cashless policy of government on corruption in Nigeria. International Review of Management and Business Research, 2(3), $682-690$.

Bakre, O. M., \& Lauwo, S. (2016). Privatisation and accountability in a "crony capitalist" Nigerian state. Critical Perspectives on Accounting, 39: 45-58.

Buhari, M. (2019). I'll continue to deal with looters, Buhari vows. The Punch, January 18.

Dutt, P. (2009). Trade protection and bureaucratic corruption: An empirical investigation. Canadian Journal of Economics 42(1), 155 - 183. Accessed from https://faculty.insead.edu/pushan-dutt

Economic \& Financial Crimes Commission (Establishment) Act (2004). Abuja: Government Printers.

Eme, O. I., \& Okeke, M. I. (2017). Buhari presidency and federal character in Nigeria: A Human Needs Theory Perspective. International Journal of Philosophy and Social-Psychological Sciences, $74-90$.

Eme, O. I., \& Onuigbo, R. A. (2016). Buhari Presidency and Ethnic Balancing in Nigeria. Nigerian Journal of Social Sciences, 12(1), $8-28$.

France, G. (2019). Kyrgyzstan: Overview of corruption and anti-corruption. Transparency International.

Gafar, B. B. (2017). The travail of service delivery and developmental failure in post- independence Nigeria. Journal of Public Administration and Policy Research, 9(3), 26-33.

Harris, K. (2017). A social revolution: Politics and the welfare state in Iran. University of California Press.

Ibietan, J. (2013). Corruption and public accountability in the Nigerian public sector: Interrogating the omission. European Journal of Business and Management, 5(15), 41- 48.

Imhonopi, D., \& Urim, U. M. (2016). Expensive democratic politics and unemployment in Nigeria: A comparison with China.

Inokoba, P., \& Ibegu, W. (2011). Economic and Financial Crime Commission (EFCC) and Political Corruption: Implication for the Consolidation of Democracy in Nigeria. Anthropologist, 13(4), 283-291. Accessed from http://www.krepublishers.com/02- Journals.pdf on 20/7/2020

Joshua, S., \& Oni, S. (2014). The Nigerian House of Representatives and corruption, (1999-2011). Mediterranean Journal of Social Sciences, 5(2), $561-567$

Keeper, D. G. (2010). Systemic corruption in Nigeria: A threat to sustainable development, In Proceedings of the first International Technology Education and Environment Conference, 172 - 178. Accessed from https://www.researchgate.net on 13/6/2020

Nnanna, O. (2020). Nepotism, the worst form of corruption. Vanguard View Point, Monday, June 29.

Nwaodu, N., Adam, D., \& Okereke, O. (2014). A review of anti-corruption wars in Nigeria. Africa's Public Service Delivery \& Performance Review, 2(3), 153-174.

Nwoba, M. O. E., \& Monday, N. P. (2018). Appraisal of Economic and Financial Crimes Commission (EFCC) in the fight against corruption in Nigeria (2007-2017). The Social Sciences, 13(1), $94-104$.

Ogbeidi, M. M. (2012). Political leadership and corruption in Nigeria since 1960: A socio-economic analysis. Journal of Nigeria Studies, 1(2), $1-25$.

Ogbodo, A. (2015). Redefining corruption at 55 (2). The Guardian, 32(13,432), 10

Ojo, F. (2016). Corruption on sabbatical. The Punch Viewpoint, Friday, February 12.

Ojo, F. (2020). The rule of idiots. The Punch Viewpoint, Friday August, 16.

Oke, T, (2020). EFCC: Time for a civilian head. The Punch, Tuesday, July 14.

Oke, T. (2014), "Financial crime prosecution, legal certainty and exigency of policy: case of Nigeria's EFCC", Journal of Financial Crime, 21(1), 56 - 65. https://doi.org/10.1108/JFC-06-2013-0044

Okeyim, M. O., Ejue, J. B., \& Ekanem, S. A. (2013). Governance and Corruption in Nigeria: A philo-psychological Analysis. Net Journal of Social Sciences, 1(2), $24-32$.

Olutokun, A. (2020). Still on Magu: Reinventing the anti-graft war. The Punch, Friday, July 17

Orokpo Ogbole, F. E. (2018). An appraisal of the Economic and Financial Crimes Commission (EFCC) in Nigeria 2002-2015.

A Doctoral Dissertation Submitted to the Department of Political Science, Faculty of Social Sciences, Benue State University, Makurdi.

Stephen, M. R., \& Orokpo, o. F. (Nd). The theory of political obligations and abuse of office in Nigeria. Retrieved from https://cloudfront.net/Political Obligation Paper.pdf on 8. 09. 2020

Oshiomole, A. A. (2019). Join APC and all your sins will be forgiven. Accessed from saharareporters.com on 23/8/2020 
(C) PAULE Ofuebe

Osinbajo, Y. (2016). Nigerian government under threat of corruption. An address delivered at the 7th Founders Day and 4th convocation Ceremony of Afe Babalola University, Ado Ekiti (ABUAD), Friday, October 21.

Osoba, S. O. (1996). Corruption in Nigeria: Historical perspectives. Review of African Political Economy, 23(69), 371 386

Page, M. T. (2018). New taxonomy for corruption in Nigeria. Carnegie Endowment for International Peace.

Persson, A. Rothstein, B. Teorell, J. (2010). The failure of anti-corruption policies: A theoretical mischaracterization of the problem. QoG Working Paper Series 2010:19 Department of Political Science University of Gothenburg, June.

The Premium Times (2020). Available at premiumtimesng.com accessed on 2. 09. 2020

Pressman, J. \& Wildavvsky, A. (1973). Implementation. Berkeley: University of California Press.

Pülzl, H. \& Treib, O. (2007). Implementing public policy. In F. Fischer, G.J. Miller \& M.S. Sidney (Eds) Handbook of Public Policy Analysis. New York: CRC Press-Taylor \& Francis Group.

Swaleheen, M. (2011). Economic growth with endogenous corruption: an empirical study. Public Choice, 146(1-2), 2341.

The 1999 Constitution of the Federal Republic of Nigeria as Amended. Abuja: Government Printers

Umar, I., Shamsiah, B. S. R. \& Bin Mohamed, M. (2016). Challenges of the Economic and Financial Crimes Commission and Their Influence on Adoption of Forensic Accounting: A Conceptual Framework. A paper presented at the Qualitative Research Conference (QRC), Penang-Malaysia, 24 - 26 May.

(c) $($ )

(C) 2020 by the authors. Licensee Research \& Innovation Initiative, Michigan, USA. This article is an open-access article distributed under the terms and conditions of the Creative Commons Attribution (CC-BY) license (http://creativecommons.org/licenses/by/4.0/).

\section{Appendix: Corruptions in Pictures}

\section{Appendix I}

\section{Abandoned Government Houses in Ikoyi- Lagos}

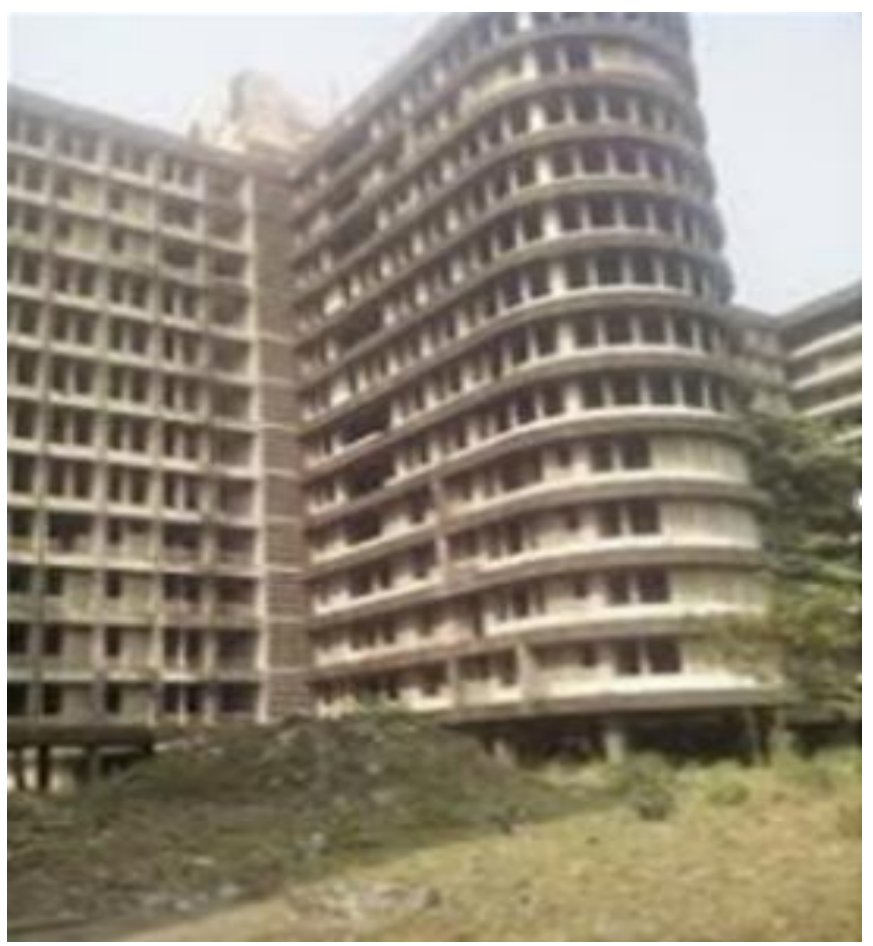

The Abandoned Government House Complex at the III Arms Zone, behind the Alex Ekwueme Square, Awka, Anambra state

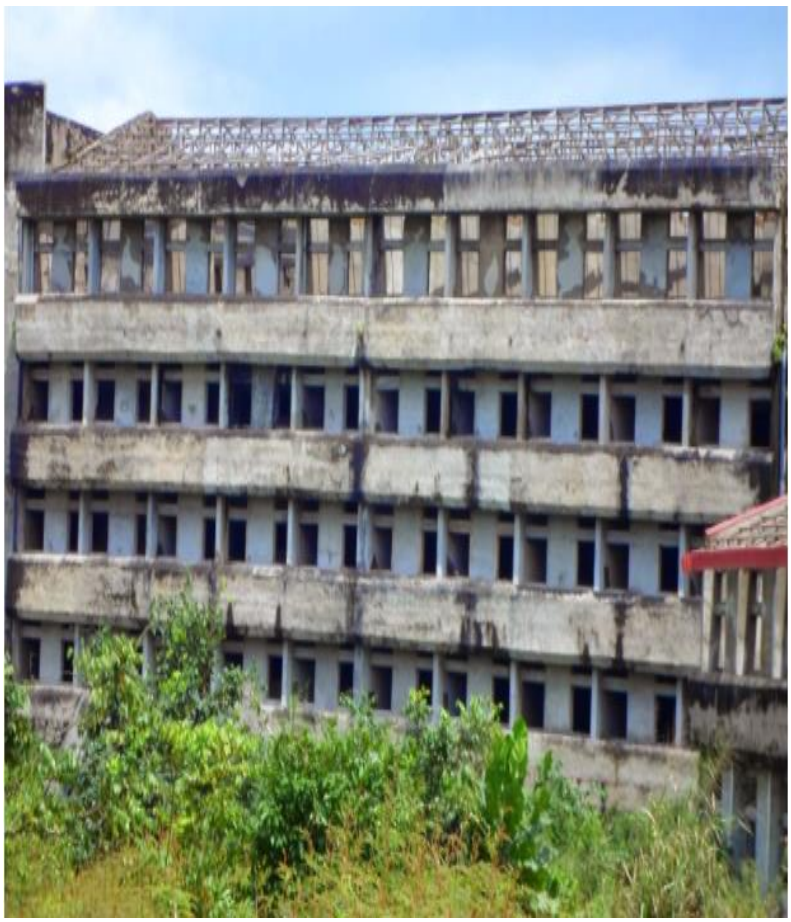

Source: The Authors' Survey (2019) 


\section{Appendix II}

Suffering of commuters on Auchi-BeninLokoja Federal Highway
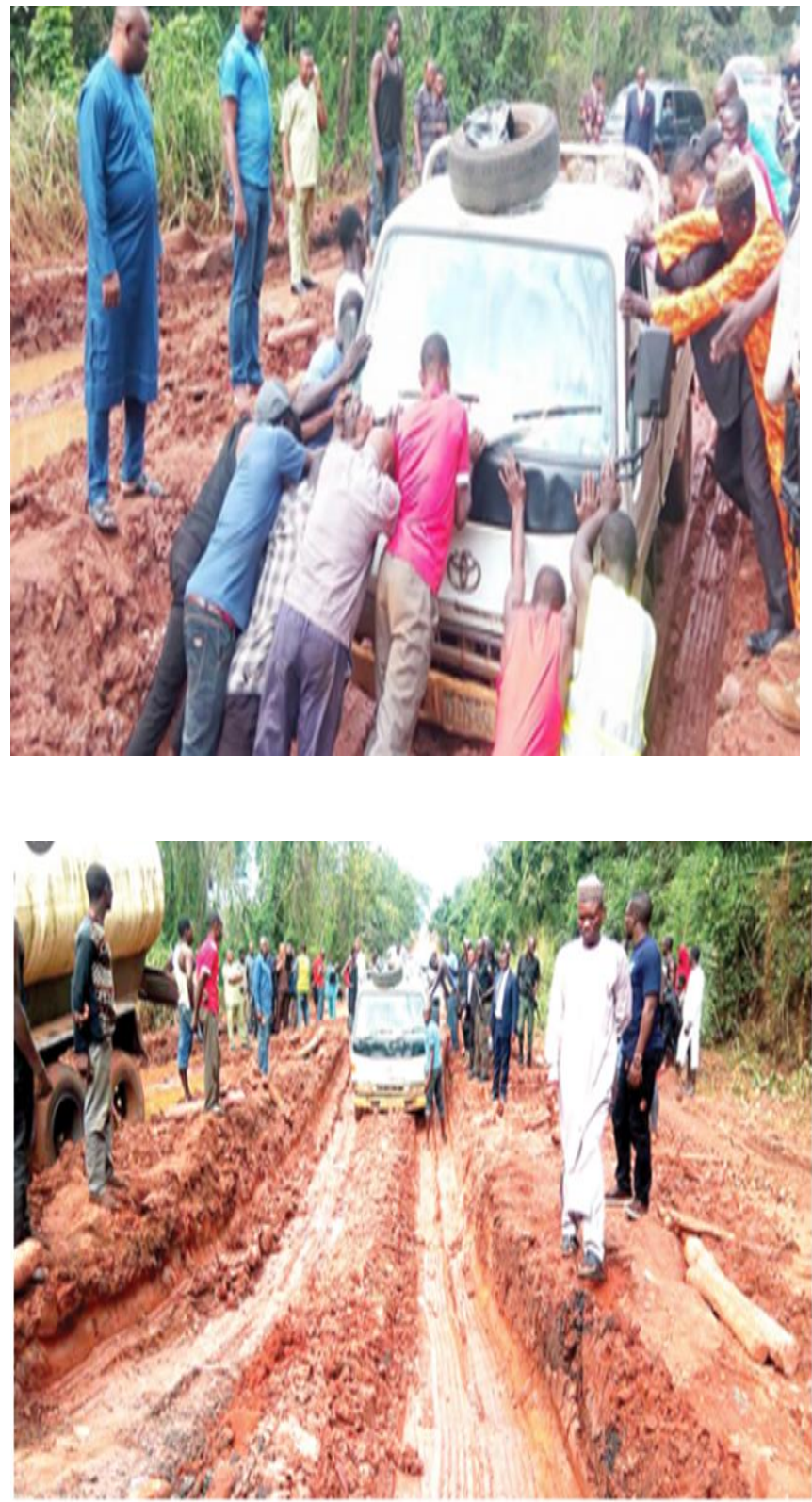

Source: The Authors' Survey (2019)
Appendix III

Children in Elementary Learning Situations and Infrastructure in Public Schools
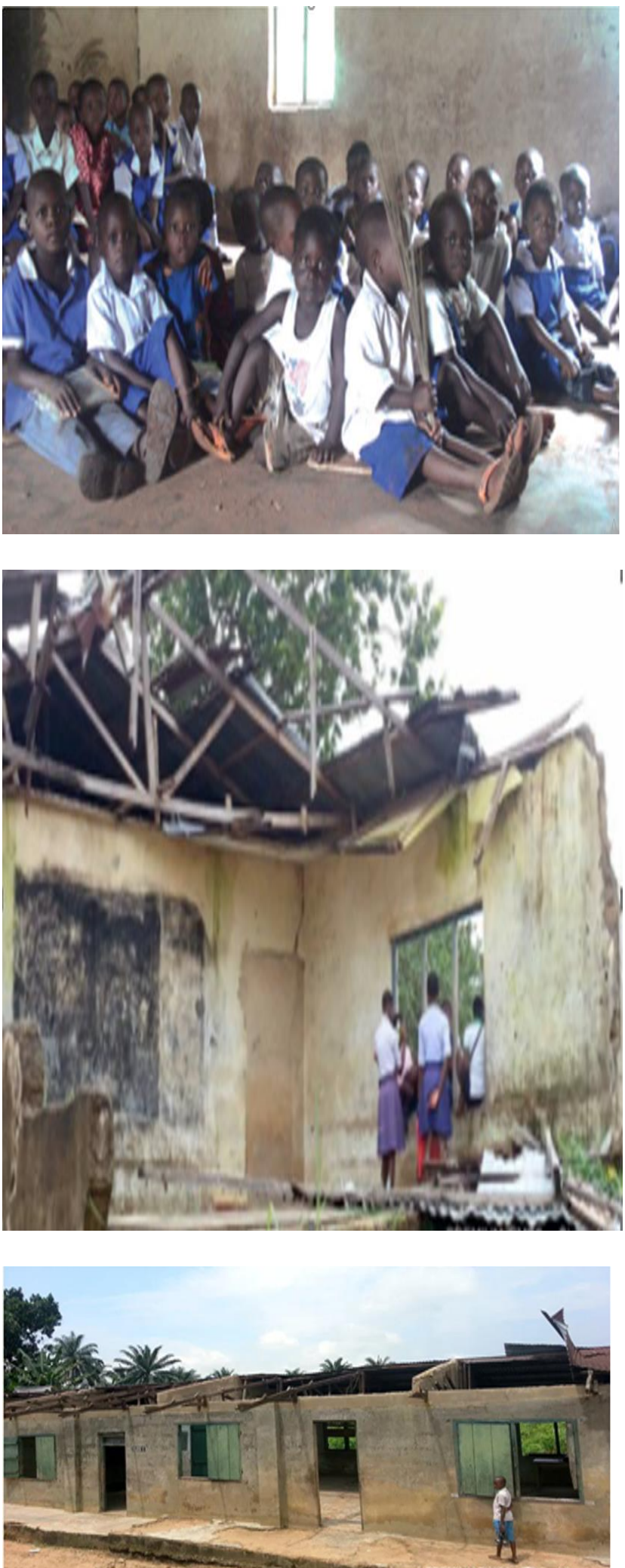

Source: Premium Times (2020) 